\title{
Nitrogen retention in the pig
}

\author{
By J. R. CARR, * K. N. BOORMAN AND D. J. A. COLE \\ University of Nottingham School of Agriculture, Sutton Bonington, \\ Loughborough, Leics. LE\2 ${ }_{5} R D$
}

(Received 10 November 1975 - Accepted 24 August 1976)

\begin{abstract}
1. Published results have been used to study the relationships between nitrogen retention $(\mathrm{NR})$, body-weight $(\mathrm{W})$ and $\mathrm{N}$ intake in the pig.

2. The general decrease in maximal $\mathrm{NR}\left(\mathrm{g} / \mathrm{d}\right.$ per $\mathrm{kg} \mathrm{W}^{\mathbf{0 . 7 5}}$ ) with increasing $\mathrm{W}(\mathrm{kg})$ was curvilinear for values of $W$ from 1.5 to $45: N R=3.324-0.098 \mathrm{~W}+0.001 \mathrm{~W}^{2}$; and rectilinear for values of $\mathrm{W}$ from 45 to $165: N R=1 \cdot 252-0.006 \mathrm{~W}$. Values for protein requirements derived from these equations agreed closely with published estimates.

3. The slopes of the curves for NR $\left(\mathrm{g} / \mathrm{d}\right.$ per $\left.\mathrm{kg} \mathrm{W}^{0.75}\right) v . \mathrm{N}$ intake $(\mathrm{g} / \mathrm{d})$ decreased as W $(\mathrm{kg})$ increased from about 2.5 to 190 . After extrapolation to a proposed common intercept on the $\mathrm{NR}$ axis of $-150 \mathrm{mg} \mathrm{N} / \mathrm{d}$ per $\mathrm{kg} \mathrm{W}^{\mathbf{0 . 7 5}}$, regression analysis of the intercepts of these curves on the $\mathrm{N}$-intake axis $v$. W gave an estimate of $\mathrm{N}$ requirements for maintenance of $246 \pm 19 \mathrm{mg} / \mathrm{d}$ per $\mathrm{kg} \mathrm{W^{0.75 }}$.

4. The results also indicated that at low $\mathrm{N}$ intakes net protein utilization ( $\mathrm{N}$ retention+ total obligatory $N$ losses $\div N$ intake) was essentially independent of $W$, whereas the gross efficiency of $\mathrm{N}$ utilization ( $\mathrm{NR} \div \mathrm{N}$ intake) was influenced by both $\mathrm{W}$ and $\mathrm{N}$ intake.
\end{abstract}

Protein and energy intakes are fundamental factors determining the productive performance of pigs and whereas the principles underlying energy metabolism and requirements of pigs, and of farm animals in general, are well documented, equivalent information on protein nutrition is scattered or lacking. Recent reviews of the responses of pigs to variation in dietary protein (Agricultural Research Council, 1967; Chamberlain, 1972; Rérat, 1972) give the impression of some confusion and this is reflected in conclusions on protein requirements and energy-protein interactions.

Thus there is a need for clarification of the principles underlying the protein nutrition of pigs and towards this end we have used published results to study some of the factors which govern the responses of pigs to changes in protein intake. Responses are described in terms of nitrogen retention (NR) measured either by carcass analysis or $\mathrm{N}$ balance. Although there are discrepancies between these methods (Duncan, 1966; Waterlow, 1969), we consider that with regard to the aims of this paper, and compared with growth rate for example, NR is a more specific way of describing response particularly in the instance of the pig which may be prone to obesity. As many aspects of protein metabolism are related allometrically to body size (Munro, I969), NR is expressed as $\mathrm{g} \mathrm{N} / \mathrm{kg}$ body-weight $(\mathrm{W})^{0.75} . \mathrm{W}^{0.75}$ is considered appropriate for comparisons between different species of farm animal (Kleiber, 1964) and is widely used in studies of both the energy and protein metabolism of pigs.

* Present address: Massey University, Paimerston North, New Zealand. 
THE DETERMINANTS OF NR

$W$. The lower limit to NR is described by total obligatory $\mathrm{N}$ loss and varies with factors such as $\mathrm{N}$ status and energy intake (Jacquot \& Peret, 1972). From information relating to a variety of species, including the pig, the relationship between $W(\mathrm{~kg})$ and endogenous urinary $\mathrm{N}$ loss $\left(Y_{1}, \mathrm{mg} / \mathrm{d}\right)$ has been described by equation ( $\mathrm{I}$ ) (Brody, 1945):

$$
Y_{1}=146 \mathrm{~W}^{0.72} .
$$

As a comparison, the relationship derived by re-calculation of FAO/WHO (1973) values for humans is given in equation (2):

$$
Y_{1}=105 \mathrm{~W}^{0.75} .
$$

Whereas Brody (1945) only considered urinary loss, the FAO/WHO (1973) report recognized that $\mathrm{N}$ losses via faeces, skin and miscellaneous routes must also be included in total obligatory losses for animals fed on protein-free diets. Re-calculation of the FAO/WHO (1973) values, including all sources of $\mathrm{N}$ loss $\left(Y_{2}, \mathrm{mg} / \mathrm{d}\right)$, provides the relationship given in equation (3):

$$
Y_{2}=\mathrm{I} 53 \mathrm{~W}^{0.75} .
$$

Although values for $\mathrm{W}$ are omitted, the results of Rippel, Harman, Jensen, Norton \& Becker (1965) indicate that minimal obligatory $\mathrm{N}$ losses are within the range $100-$ $190 \mathrm{mg} / \mathrm{d}$ per $\mathrm{kg} \mathrm{W} \mathrm{W}^{0.75}$ in the gravid gilt. The corresponding range reported by Armstrong \& Mitchell (1955) for the growing pig is $106-19 \mathrm{I} \mathrm{mg} / \mathrm{d}$ per $\mathrm{kg} \mathrm{W} \mathrm{W}^{0.75}$, and Homb (1972) used a value of $160 \mathrm{mg} / \mathrm{d}$ per $\mathrm{kg} \mathrm{W}^{0.75}$ for the endogenous urinary $\mathrm{N}$ plus 'integumental losses' for the pig.

Thus a value of $-150 \mathrm{mg} / \mathrm{d}$ per $\mathrm{kg} \mathrm{W}^{0.75}$ is proposed as an estimate of the lower boundary to $\mathrm{N}$ balance in $\mathrm{N}$-depleted pigs ingesting adequate amounts of energy. This value is similar to corresponding values determined with humans (Chan \& Waterlow, 1966; Calloway \& Margen, r97I; Scrimshaw, Davy, Perera \& Young, I976) and lambs (Black \& Griffiths, I975).

Theoretically, in ideal conditions of diet and environment, the upper limit to NR will be determined by genotype and endocrine status. From the results of published experiments which were judged to have few dietary or environmental constraints to the attainment of maximum NR (Manners \& McCrea, r963; Oslage \& Fliegel, r964; Fuller, 1965; Wood \& Groves, 1965; Elsley, Anderson, McDonald, MacPherson \& Smart, I966; Piatkowski \& Jung, I 966; Thorbek, I969a; Braude, Mitchell, Newport $\&$ Porter, 1970; Braude, Newport \& Porter, I 971 ; Braude \& Newport, 1973), a relationship between maximum NR and $\mathrm{W}$ can be derived (Fig. r). In agreement with findings that there is a decreasing intensity of many measurements of protein metabolism as the size of the species increases (Munro, 1969), and a decrease in the rate of total body protein synthesis with age in man (Young, Steffee, Pencharz, Winterer \& Scrimshaw, 1975), maximum potential NR in the pig decreases with W. 


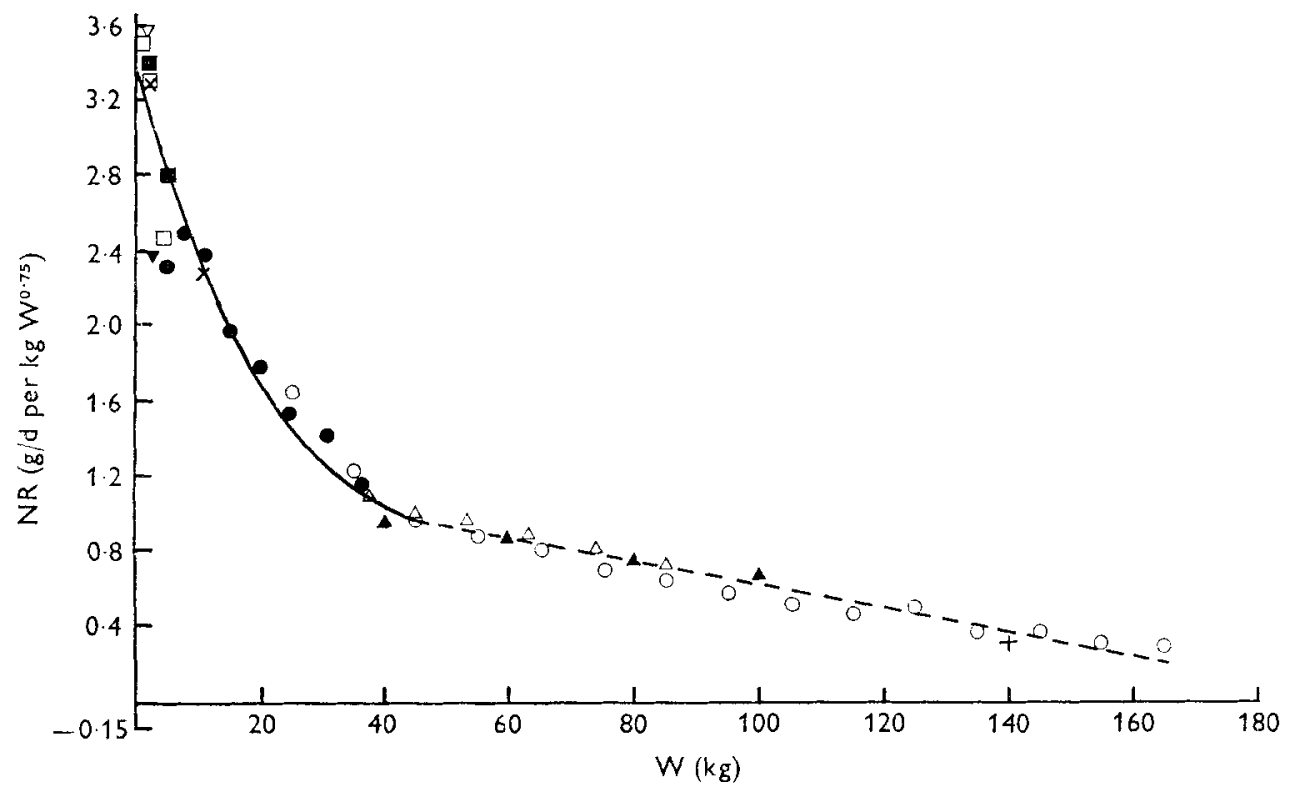

Fig. I. 'The relationship between nitrogen retention (NR) (g/d per kg body-weight $(\mathrm{W})^{0^{*}}{ }^{5}$ ) and $\mathrm{W}(\mathrm{kg})$ in the pig: sources of values: ( $\square$ ), Manners \& McCrea (r963); ( $\bigcirc)$, Oslage \& Fliegel (1964); (๑), Fuller (1965); ( $\mathbf{1})$, Wood \& Groves (1965); (+), Elsley, Anderson, McDonald, Macpherson \& Smart (1966); (A), Piatkowski \& Jung (I966); ( $\triangle$ ), Thorbek (1969a); ( $\nabla)$, Braude, Mitchell, Newport \& Porter (1970); (E), Braude, Newport \& Porter (1971); (X), Braude \& Newport (1973). Fitted functions:

$$
(-), N R=3.324-0.098 \mathrm{~W}+0.001 \mathrm{~W}^{2} ;(--), \mathrm{NR}=\mathrm{I} \cdot 252-0.006 \mathrm{~W} \text {. }
$$

The curve shown in Fig. $\mathrm{I}$ is described by the grafted function (Fuller, I969) given in equation (4):

$$
\begin{aligned}
\mathrm{NR}= & 3.324-0.098 \pm 0.005 \mathrm{I} \mathrm{W}+0.00 \mathrm{I} \pm 0.000 \mathrm{I} Z, \\
& \left(R^{2} 0.96 \mathrm{I}, \text { residual mean square } 0.042\right)
\end{aligned}
$$

where $Z=\mathrm{W}^{2}$ for values of $\mathrm{W} \leqslant 45 \mathrm{~kg}$, and $45 \times(2 \mathrm{~W}-45)$ for values of $\mathrm{W} \geqslant 45 \mathrm{~kg}$. This function is quadratic for $\mathrm{W} \leqslant 45 \mathrm{~kg}\left(\mathrm{NR}=3.324-0.098 \mathrm{~W}+0.00 \mathrm{I} \mathrm{W}^{2}\right)$ and linear for $\mathrm{W} \geqslant 45 \mathrm{~kg}(\mathrm{NR}=\mathrm{I} \cdot 252-0.006 \mathrm{~W})$. The two functions were estimated simultaneously by least squares regression, subject to the constraints that the estimated value for the dependent variable and the estimated value for the first derivatives of the two equations should be equal at the value of $\mathrm{W}$ where they were grafted together. The residual mean square from regression was minimized where this value of $\mathrm{W}$ was $45 \mathrm{~kg}$.

The values used in deriving the function are from experiments in which different sexes (female, entire male and castrated male) of the Large White and Landrace breeds were used. Curves derived separately for each sex would differ (Piatkowski \& Jung, I966), since at the same $\mathrm{W}$ entire males retain more $\mathrm{N}$ than females, and the latter retain more $\mathrm{N}$ than castrated males. These differences are proportionally greater at higher values for $\mathrm{W}$ (Nielsen, I97I), and, if involving castrates, are probably also a function of the age at which the animal is castrated (Charette, 1961). There is 


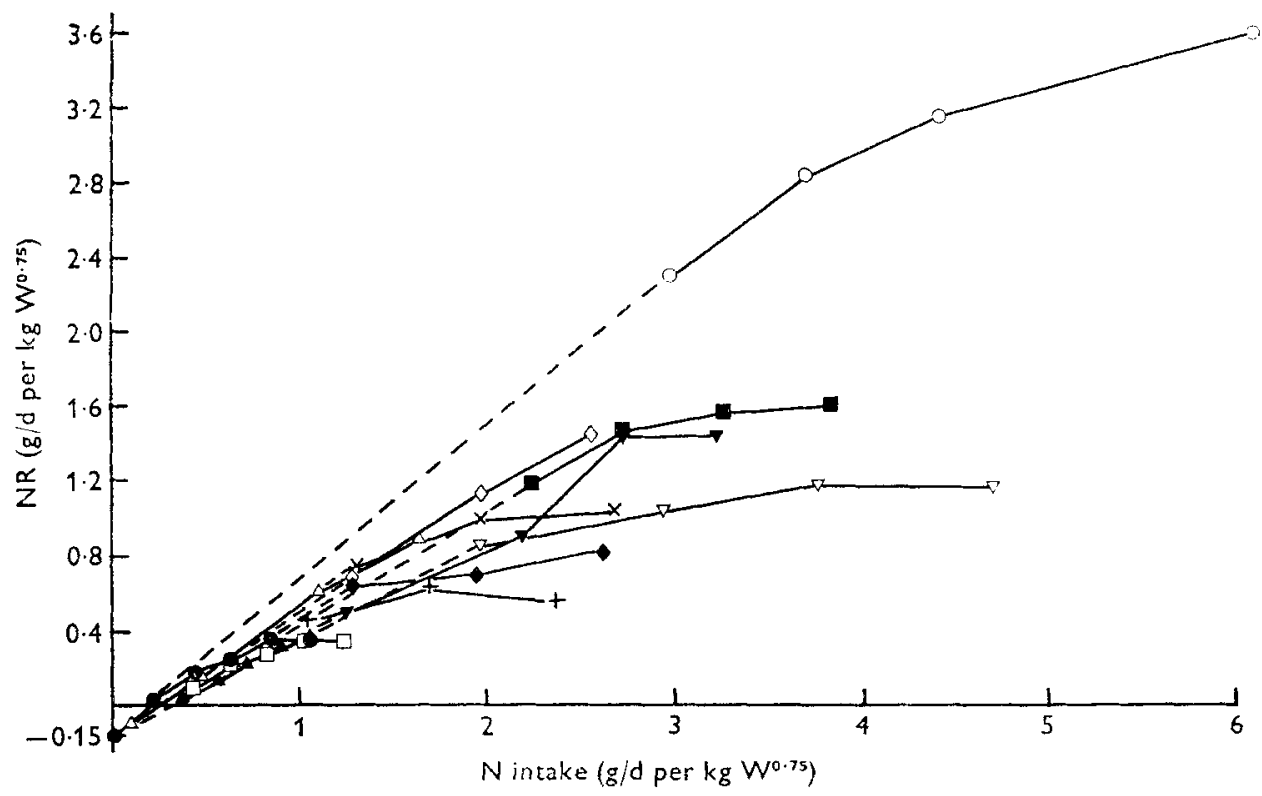

Fig. 2. The relationship between nitrogen retention (NR) (g/d per kg body-weight $(W)^{0.75}$ ) and $N$ intake ( $/ \mathrm{d}$ per $\mathrm{kg} W^{0.75}$ ) in pigs of various $W(\mathrm{~kg})$ : sources of values : $(\triangle)$, Armstrong $\&$ Mitchell (1955), W 34.8; (V), Jones, Hepburn \& Boyne (I96I), W I 5 ; (D), Rutledge, Hanson \& Meade (I96I), W I $;(\bigcirc),(x),(\bullet),(+)$, Rérat \& Henry (1964), W 37, 52, 68.5, 85 respec-

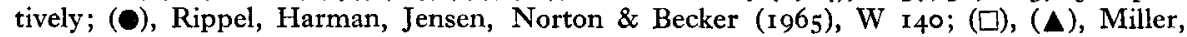
Becker, Jensen, Harman \& Norton (1969), W I 58, r 9 I respectively; ( $\nabla)$, Wyllie, Speer, Ewan \& Hays (1969), W 14.4; (O), Braude, Mitchell, Newport \& Porter (1970), W 2.5; (- - -), extrapolations to $\mathrm{N}$ intake of $\circ \mathrm{g} / \mathrm{d}$ per $\mathrm{kg} \mathrm{W^{0.75 }}$.

insufficient published information to enable a precise description of the curve for each sex. It is likely that similar differences occur between breeds and strains.

Allowing that sex and breed will cause variations, the function given in equation (4) is an estimate of the upper limit to NR in pigs. Thus assuming that total obligatory $\mathrm{N}$ losses are approximately constant with age when expressed as a function of $\mathrm{W}^{0 \cdot 75}$, $N R$ in the pig must always lie beneath the curve in Fig. I including values to $-0.150 \mathrm{~g} / \mathrm{d}$ per $\mathrm{kg} \mathrm{W}^{0.75}$, irrespective of prevailing dietary or environmental circumstances.

$N$ intake. When protein deposition is limited by $\mathrm{N}$ intake increases in the latter cause increases in NR (Munro, 1964). From selected published information from experiments in which protein quality and energy intake were judged adequate (Armstrong \& Mitchell, I955; Jones, Hepburn \& Boyne, r96r; Rutledge, Hanson \& Meade, I96I; Rérat \& Henry, 1964; Rippel et al. 1965; Miller, Becker, Jensen, Harman \& Norton, 1969; Wyllie, Speer, Ewan \& Hays, r969; Braude et al. 1970) this relationship can be illustrated for pigs with values of $W$ varying from approximately 2.5 to $190 \mathrm{~kg}$ and is shown in Fig. 2. Where pertinent, extrapolation of the response curves to the proposed lower limit to $\mathrm{N}$ balance ( $-\mathrm{I} 50 \mathrm{mg} / \mathrm{d}$ per $\mathrm{kg} 0.75$ ) seems acceptable. Statistical validation is not possible because with the two exceptions already considered in arriving at this proposed value (Armstrong \& Mitchell, 1955; Rippel 
et al. 1965), the sets of values do not cover sufficiently wide ranges over the linear parts of the relationships (Allison, 1964) to permit examination of the intercepts by regression. With this limitation Fig. 2 supports the assumption previously made that total obligatory $\mathrm{N}$ losses in the pig are approximately constant with age when expressed as a function of $\mathrm{W}^{0.75}$, which is contrary to the view of Bell \& Loosli (195 I). Obligatory $\mathrm{N}$ losses of young and elderly women are however reported to be similar (Scrimshaw et al. 1976) when expressed per unit body-weight.

There is no conclusive published information for any species concerning the effect of age or $\mathrm{W}$ on the classical indices of protein quality based on body $\mathrm{N}$ changes (Payne, 1972), e.g. biological value (Bv) and net protein utilization (NPU; $N$ retention + total obligatory $\mathrm{N}$ losses $\div \mathrm{N}$ intake). Payne (1972) suggested that these indices, and hence the slopes of the linear parts of the curves for $\mathrm{N}$ intake $v$. NR (McLaughlin \& Campbell, 1969) are probably constant with age. The information illustrated in Fig. 2 suggests this to be so for pigs varying from infancy to almost mature body size.

The maximum NR defined by each curve in Fig. 2 should coincide with the maximum potential NR described in Fig. I, for a pig of corresponding W. However, energy supply can limit protein deposition and therefore energy intake may impose a limit on the NR achieved (Heard, I964; Munro, 1964; Kielanowski, I967; Payne, 1972). Under these circumstances the curve for NR $v$. N intake ends at a point below its maximum, which is determined by the severity of energy insufficiency (Miller \& Payne, 1964; Allison, 1964; Balch, 1967; Black \& Griffiths, 1975). Thus a new threshold to NR is established which is lower than that determined by W. Evidence for interactions between the effects of dietary energy and protein in their effects on NR in the pig is provided by the trends in the growth information reported by Cooke, Lodge \& Lewis (I972), if NR and rate of gain are regarded as closely correlated traits (Kielanowski, 1967).

Under controlled feeding regimens increases in $\mathrm{N}$ intake greater than that needed to support maximum NR, whether this be determined by W or energy intake, result in decreases in the rate and efficiency of gain (Agricultural Research Council, i967; Chamberlain, 1972; Rérat, I972). These decreases reflect the decrease in the proportions of the digestible energy (DE) represented by metabolizable energy (ME) and net energy, as an increasing proportion of $\mathrm{DE}$ is provided by protein rather than nonprotein sources (Klieber, 196r; Leroy, 1965; Thorbek, 1969 $b$; Whittemore \& Fawcett, 1974; Morgan, Cole \& Lewis, 1975). Excessive intakes of $\mathrm{N}$ may further inhibit growth by reducing food consumption (Sugahara, Baker, Harman \& Jensen, 1969). For the same reasons, and perhaps the additional decreasing influence of high protein intakes on lipogenesis ( $\mathrm{O}^{\prime} \mathrm{Hea} \&$ Leveille, 1969), the proportion (but not the quantity) of lean in the body might be expected to increase as $\mathbf{N}$ intake exceeds the requirement for maximum NR (Agricultural Research Council, 1967; Chamberlain, 1972; Lodge, Hardy \& Lewis, I972; Rérat, 1972).

The slopes of the curves for NR $v$. N intake (Fig. 2) are not only functions of W, but are also influenced by such factors as the quality of dietary protein and sex. For a particular W, the slope decreases as protein quality deteriorates (Allison, 1964), and is probably less for castrated males than for females or entire males (Bell, I965; 


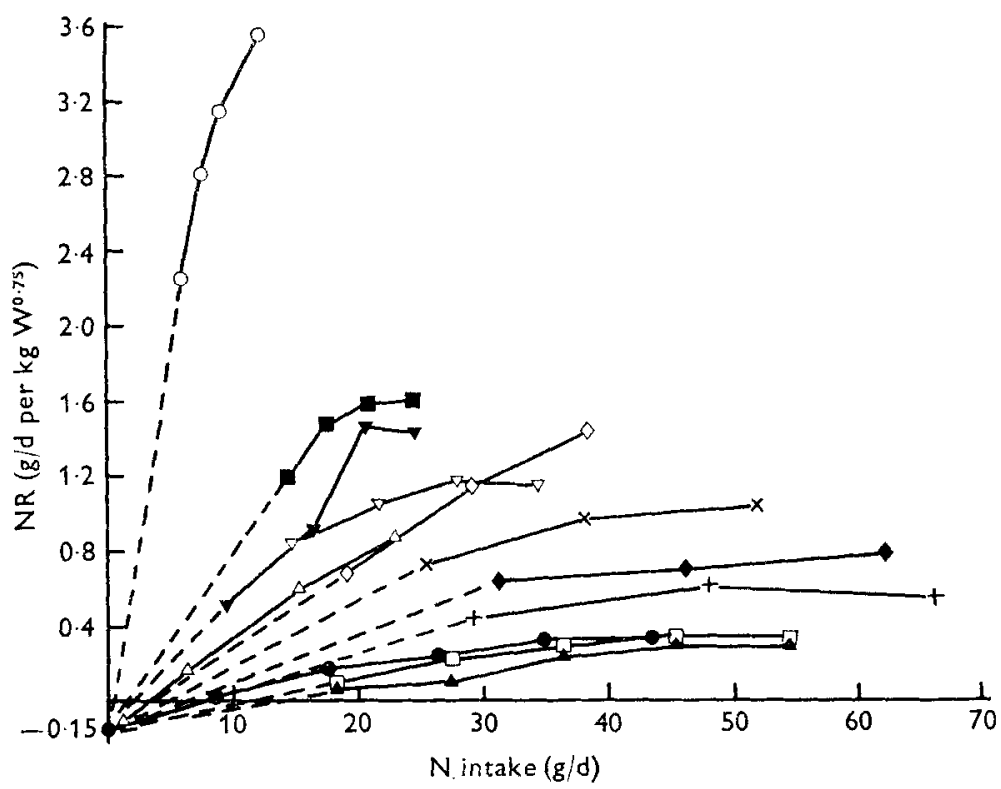

Fig. 3. The relationship between nitrogen retention (NR) (g/d per kg body-weight (W) ${ }^{0.75}$ ) and $N$ intake $(\mathrm{g} / \mathrm{d})$ in pigs of various $W(\mathrm{~kg})$ : sources of values: $(\triangle)$, Armstrong $\&$ Mitchell (I955), W 34.8; ( $\mathbf{V}$ ), Jones, Hepburn \& Boyne (I96I), W I5; (D), Rutledge, Hanson \& Meade (I96I), W I2; ( $\diamond),(\times)$, ( $)$, (t), Rérat \& Henry (Ig64), W 37, 52, 68.5, 85 respec-

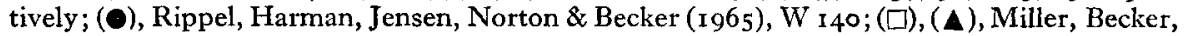
Jensen, Harman \& Norton ( 1969 ), W I $_{5} 8$, i91 respectively; ( $\left.\nabla\right)$, Wyllie, Speer, Ewan \& Hays (1969), W 14.4; (O), Braude, Mitchell, Newport \& Porter (1970), W 2.5; (- - -), extrapolations to $\mathrm{N}$ intake of $\mathrm{g} / \mathrm{d}$.

Prescott \& Lamming, I967; Bayley \& Summers, I968; Lucas \& Miles, 1970; Davies $\&$ Lucas, 1972). There is no published information which allows the effects of these variables on the relationship between $\mathrm{NR}$ and $\mathrm{N}$ intake to be described quantitatively. With respect to protein quality, the approach of the FAO/WHO (1973) for humans could be adopted for pigs, using current recommendations for amino acid requirements as a basis for describing an operative reference protein.

\section{ESTIMATES OF PROTEIN REQUIREMENTS}

Maintenance. In order to facilitate estimation of the $\mathrm{N}$ requirements for maintenance $\left(N_{m}\right)$, the relationships shown in Fig. 2 were recalculated using $\mathrm{g} / \mathrm{d}$ as the unit of $\mathrm{N}$ intake (Fig. 3), the intercepts on the $\mathrm{N}$-intake axis $(\mathrm{NR}=0)$ then providing estimates of $N_{m}$ for pigs of various W. These estimates are presented in Fig. 4. The regression line fitted through the origin to these values is described by equation (5):

$$
N_{m}=0.246 \pm 0.019 \mathrm{~W}^{0.75} \text {. }
$$

Whereas this estimate of $N_{m}\left(0.246 \mathrm{~g} / \mathrm{d}\right.$ per $\left.\mathrm{kg} \mathrm{W} \mathrm{W}^{0.75}\right)$ is less than half that proposed by Brody (1945), it agrees very closely with the synthetic value $(0.250 \mathrm{~g} / \mathrm{d}$ per $\mathrm{kg}$ $\mathrm{W}^{0.75}$ ) derived by Miller \& Payne (1964) for mammals in general and those which may be calculated from the FAO/WHO (1973) values for man, when dietary protein is of 


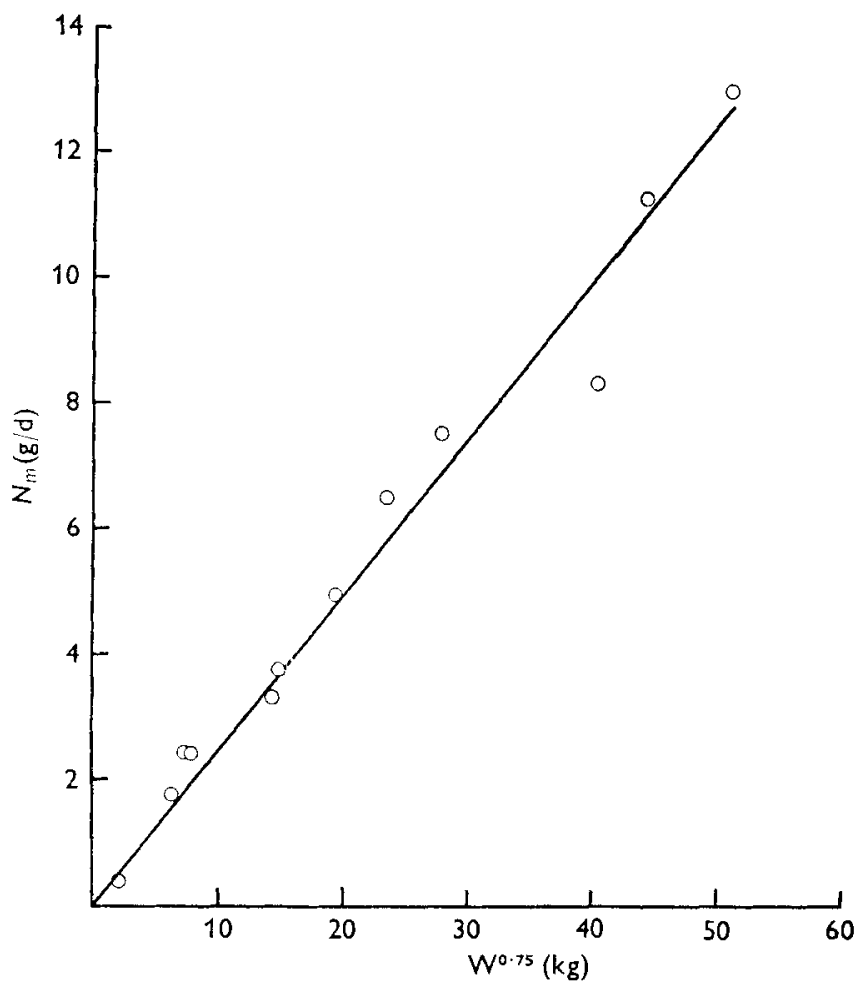

Fig. 4. Estimates of the nitrogen requirements for maintenance $\left(N_{m}\right)(\mathrm{g} / \mathrm{d})$ of pigs of various metabolic body sizes (body-weight $\left.(W)^{0.75}\right)(\mathrm{kg})$ : sources of values: Armstrong \& Mitchell (I955); Jones, Hepburn \& Boyne (I96I); Rutledge, Hanson \& Meade (I96I); Rérat \& Henry (I964); Rippel, Harman, Jensen, Norton \& Becker (1965); Miller, Becker, Jensen, Harman \& Norton (I969); Wyllie, Speer, Ewan \& Hays (I969); Braude, Mitchell, Newport \& Porter (1970). Regression equation: $N_{m}=0.246 \pm 0.019 \mathrm{~W}^{0.75}$.

vegetable $\left(0.264 \mathrm{~g} / \mathrm{d}\right.$ per $\left.\mathrm{kg} \mathrm{W}^{0.75}\right)$ or animal $\left(0.20 \mathrm{I} \mathrm{g} / \mathrm{d}\right.$ per $\left.\mathrm{kg} \mathrm{W}^{0.75}\right)$ origin. It is also within the same range as those for ruminating calves of $\left(\mathrm{g} / \mathrm{d}\right.$ per $\left.\mathrm{kg} \mathrm{W}^{0.75}\right) 0.330 \pm 0 .{ }_{5} 6$, $0.270 \pm 0.053$ (Stobo \& Roy, 1973), although these values are expressed in terms of apparent digestible $\mathrm{N}$.

From this estimate of $N_{m}$ and the proposed value for obligatory $\mathrm{N}$ losses presented earlier, the efficiency of $N$ utilization for maintenance is $0.61(0.150 \div 0.246)$. This compares with an efficiency of utilization of ME for maintenance of $0 \cdot 6 \circ$ (Kielanowski, 1972).

Using a value for $N_{m}$ of $0.246 \mathrm{~g} / \mathrm{d}$ per $\mathrm{kg} \mathrm{W} \mathrm{W}^{0.75}$, estimates of the maintenance requirements for $\mathrm{N}$ and crude protein $(\mathrm{CP}, \mathrm{N} \times 6.25)$ for pigs varying in $\mathrm{W}$ from 5 to I $60 \mathrm{~kg}$ can be calculated (Table I).

Since the relationship between $W$ and $M E$ requirement for maintenance $\left(\mathrm{ME}_{m}\right)$ found for the pig by Verstegen, Close, Start \& Mount (I973) is:

$$
\mathrm{ME}_{m}(\mathrm{MJ} / \mathrm{d})=0.475 \mathrm{~W}^{0.75},
$$

both $N_{m}$ and $\mathrm{ME}_{m}$ are apparently proportional to metabolic body size. Thus the required value for protein: energy $(\mathrm{CP}: \mathrm{ME})$ for the diet for maintenance may be taken 
Table I. Estimates of the maintenance requirements $(g / d)$ of pigs of various body-weights $(\mathrm{kg})$ for nitrogen and crude protein $(N \times 6.25)$

(Values were calculated using a value for $\mathrm{N}$ requirement at maintenance of $0.246 \mathrm{~g} / \mathrm{d}$ per $\mathrm{kg}$ body-wt ${ }^{0.75}$ )

$\begin{array}{ccc}\text { Body-wt } & N & \text { Crude protein } \\ 5 & 0.82 & 5.1 \\ 10 & 1.38 & 8.6 \\ 20 & 2.33 & 14.6 \\ 40 & 3.91 & 24.4 \\ 60 & 5.31 & 33.2 \\ 80 & 6.57 & 41.1 \\ 100 & 7.77 & 48.6 \\ 120 & 8.91 & 55.7 \\ 140 & 10.01 & 62.6 \\ 160 & 11.04 & 69.0\end{array}$

Table 2. Estimates of the nitrogen intakes required to support maximum $N$ retention in pigs of various body-weights, and of the dietary crude protein $(N \times 6 \cdot 25)$ concentrations needed to satisfy these requirements under restricted and ad lib. feeding regimens

\begin{tabular}{|c|c|c|c|c|c|c|}
\hline \multirow[b]{2}{*}{$\begin{array}{l}\text { Body-wt } \\
\text { (kg) }\end{array}$} & \multirow[b]{2}{*}{$\begin{array}{c}\mathrm{N} \\
\text { retention* } \\
(\mathrm{g} / \mathrm{d})\end{array}$} & \multirow[b]{2}{*}{$\begin{array}{c}N \text { intake } \dagger \\
(\mathrm{g} / \mathrm{d})\end{array}$} & \multicolumn{2}{|c|}{ Restricted feeding } & \multicolumn{2}{|c|}{ Ad lib. feeding } \\
\hline & & & $\begin{array}{c}\text { Food } \\
\text { intakef } \\
(\mathrm{kg} \mathrm{DM} / \mathrm{d})\end{array}$ & $\begin{array}{c}\text { Crude } \\
\text { protein } \\
(\mathrm{g} / \mathrm{kg} \mathrm{DM})\end{array}$ & $\begin{array}{c}\text { Food } \\
\text { intakef } \\
(\mathrm{kg} \mathrm{DM} / \mathrm{d})\end{array}$ & $\begin{array}{c}\text { Crude } \\
\text { protein } \\
\text { (g/kg DM) }\end{array}$ \\
\hline 5 & $9 \cdot 6$ & $18 \cdot 3$ & - & - & 0.43 & 266 \\
\hline 10 & r3.7 & $28 \cdot 4$ & $\overline{0}$ & $-\cdots$ & 0.73 & 243 \\
\hline 20 & $16 \cdot 7$ & $39 \cdot 8$ & 0.87 & 286 & $I \cdot 22$ & 204 \\
\hline 40 & $16 \cdot 3$ & $46 \cdot 3$ & $I \cdot 61$ & I 80 & $\mathrm{I} \cdot 9 \mathrm{I}$ & 152 \\
\hline 60 & $18 \cdot 8$ & $58 \cdot 8$ & $2 \cdot 17$ & 169 & $2 \cdot 44$ & 151 \\
\hline 80 & 19.9 & $64 \cdot 8$ & $2 \cdot 61$ & 155 & $2 \cdot 87$ & 145 \\
\hline 100 & I 9.5 & $64 \cdot 8$ & $2 \cdot 85$ & 142 & 3.22 & I 26 \\
\hline 120 & 17.7 & $59 \cdot 6$ & - & - & - & 一 \\
\hline 140 & 247 & 49.7 & - & - & 一 & - \\
\hline 160 & 10.6 & $35 \cdot 8$ & $一$ & - & - & - \\
\hline
\end{tabular}

$\mathrm{DM}$, dietary dry matter.

* Derived from equation 4 , see p. 145 .

$\dagger \mathrm{N}$ retention $\div$ gross efficiency of dietary protein utilization, according to Whittemore \& Fawcett (1974).

† From Agricultural Research Council (1967).

as a constant with age or $\mathrm{W}$. The constants in equations (5) and (6) suggest that the required value is approximately $3.2 \mathrm{~g} / \mathrm{MJ}$.

Production. The relationship between the gross efficiency of dietary $\mathrm{N}$ utilization (GNU; $\mathrm{NR} \div \mathrm{N}$ intake) in the pig and $\mathrm{W}(\mathrm{kg})$ has been described by equation (7) (Whittemore \& Fawcett, 1974):

$$
\mathrm{GNU}=0.295 e^{-0.0402 \mathrm{~W}} \text {. }
$$

This equation gives values similar to those of Homb (1972) for values of W up to Ioo kg, but somewhat higher values for higher values of $\mathrm{W}$.

From equations (4) and (7) the $\mathrm{N}$ intakes required for maximum NR in pigs of various $\mathrm{W}$ can be calculated (Table 2). Although the values used in deriving the 
Table 3. Estimates of the daily crude protein (nitrogen $\times 6 \cdot 25$ ), metabolizable energy (ME) and crude protein: $\mathrm{ME}$ requirements of pigs of various body-weights

$\begin{array}{cccc}\begin{array}{c}\text { Body-wt } \\ (\mathrm{kg})\end{array} & \begin{array}{c}\text { Crude } \\ \text { protein } \\ (\mathrm{g} / \mathrm{d})\end{array} & \begin{array}{c}\mathrm{ME} \\ (\mathrm{MJ} / \mathrm{d})\end{array} & \begin{array}{c}\text { Crude } \\ \text { protein:ME }\end{array} \\ 5 & 114 & 6.2 * & 18.4 \\ 10 & 178 & 10.4^{*} & 17.1 \\ 20 & 249 & 16.1 \dagger & 15.5 \\ 40 & 289 & 24.6 \dagger & 11.7 \\ 60 & 368 & 27.9 \dagger & 13.2 \\ 80 & 405 & 30.7 \dagger & 13.2 \\ 100 & 405 & 33.0 \dagger & 12.3\end{array}$

* Obtained from the equation: $\mathrm{E}$ (kcal digestible energy (DE)/week) $=3.18 \mathrm{~W}(\mathrm{~kg})^{0.76}\left(\mathrm{I} 3.3 \mathrm{r}(\mathrm{kJ}) \mathrm{W}^{0.76}\right)$, where W is body-wt; assuming $\mathrm{ME}=0.95 \mathrm{DE}$ (Agricultural Research Council, I967).

$\uparrow$ From Kielanowski (1972).

$\ddagger$ Estimated value.

equations on which these estimates of $\mathrm{N}$ intakes are based are relatively few, and therefore the estimates themselves must be regarded as approximations, it should be noted that the food intakes providing these requirements agree closely with respective current recommendations for dietary CP contents (UK) Agricultural Research Council, I967; (US) National Research Council, 1973) derived by more conventional methods. Values given in Table 2 also indicate that maximum NR and $\mathrm{N}$ requirement to achieve this vary parabolically with age or $\mathrm{W}$; the requirement increasing to a maximum at $80-100 \mathrm{~kg} \mathrm{~W}$ (coincidental with a peak in daily NR) and subsequently decreasing, presumably, eventually, to $N_{m}$ on reaching mature size. In these respects these values agree well with those of Homb (1972), although the values for NR and $\mathrm{N}$ requirement presented here are consistently greater. The latter are lower than those recommended by the (US) National Research Council (1973). This pattern of N requirement with age differs from that proposed for humans (FAO/WHO, 1973), which shows a continuous increase from birth to maturity. This difference may be explained by the comparatively slow growth in man (Brody, 1945), which results in a relatively small $\mathrm{N}$ requirement during the juvenile period. Recommendations for protein concentrations in poultry rations (Agricultural Research Council, 1975) suggest that their daily $\mathrm{N}$ requirement also changes parabolically with age.

Using the estimated daily $\mathrm{N}$ requirements (Table 2), estimates of the daily $\mathrm{ME}$ requirements of pigs growing from 20 to $100 \mathrm{~kg}$ at an average rate of $700 \mathrm{~g} / \mathrm{d}$ (Kielanowski, 1972) and estimates of the ME requirements of early-weaned piglets (Agricultural Research Council, 1967), CP:ME requirements of pigs of W (kg) from 5 to 100 can be estimated (Table 3 ). As the requirement for protein in the diet decreases with increasing W (Table 2), so CP:ME for maximum NR tends to decrease (Table 3). If CP:ME required for maintenance remains constant with age, at about $3.2 \mathrm{~g} / \mathrm{MJ}$ as estimated previously, the requirement for maximum NR must decrease to this value at mature size. With a value of $3^{\cdot 2} \mathrm{~g} / \mathrm{MJ}$ at maintenance, it is clear from Table 3 that with the probable exception of the mature animal the desired CP:ME increases as energy and protein intakes increase above maintenance. For this reason the protein or 


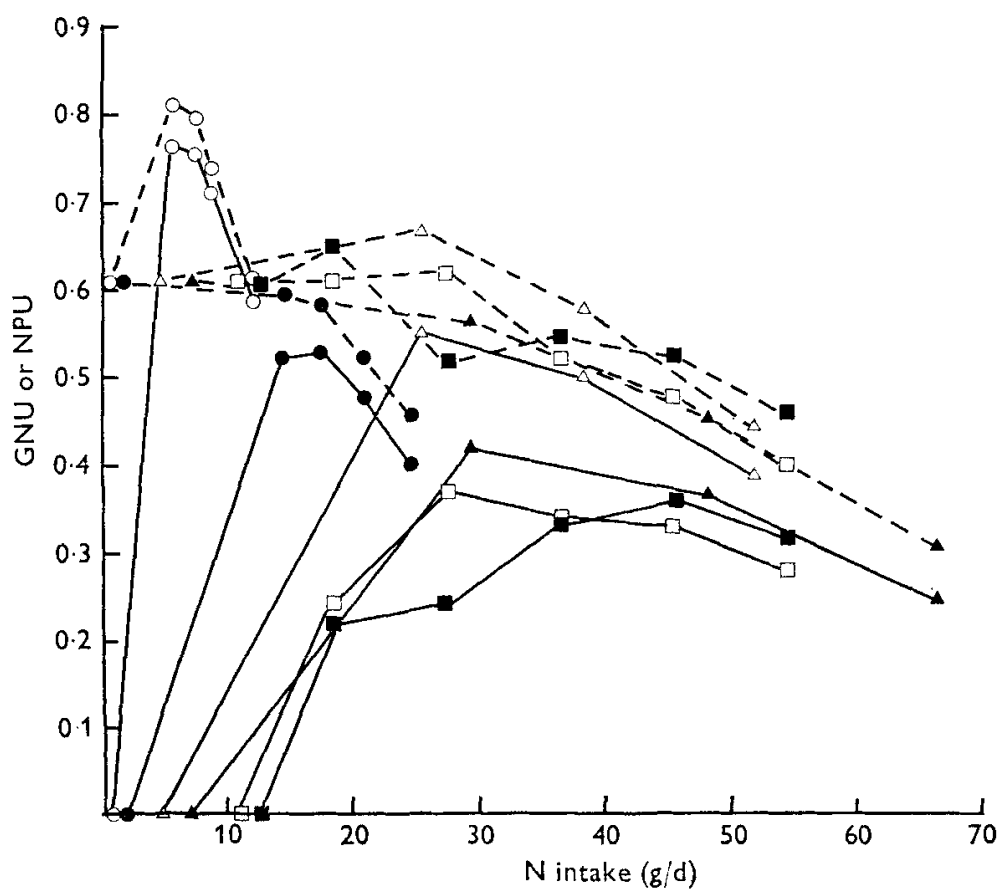

Fig. 5. The relationships between nitrogen intake $(\mathrm{g} / \mathrm{d})$ and the gross efficiency of dietary $\mathrm{N}$ utilization (GNU; $N$ retention $\div \mathrm{N}$ intake) $(-)$ and net protein utilization (NPU; $N$ retention + total obligatory $N$ losses $\div N$ intake) $(--)$ of pigs of various body-weights (W) $(\mathrm{kg})$ : sources of values: $(\odot)$, Rutledge, Hanson \& Meade (196r), W I2; $(\triangle)$, (A), Rérat \& Henry (1964), W 52, 85 respectively; ( $\square)$, ( (1969), W 1 58, x91 respectively; (O), Braude, Mitchell, Newport \& Porter (1970), W 2.5.

amino acid requirements of restrictedly-fed pigs cannot be described precisely in the customary manner, as percentages of the diet or as amounts expressed per unit of dietary energy, unless energy or food allowances are specified.

The information from which the curves for NR $v$. N intake were obtained (Figs. 2, 3) can be used to determine the relationship between $\mathrm{N}$ intake and both GNU and NPU ((NR + total obligatory $\mathrm{N}$ losses $) \div \mathrm{N}$ intake $)$ for various values of $\mathrm{W}$. For pigs these relationships are shown in Fig. 5 for six values of $W$ ranging from $2 \cdot 5$ to I $9 \mathrm{I} \mathrm{kg}$.

Evidently GNU varies curvilinearly with $\mathrm{N}$ intake and the nature of the relationship is influenced by W. Fig. 5 confirms that GNU decreases with W as predicted by equation ( 7 ), but that the magnitude of the decrease can be influenced by $\mathrm{N}$ intake. The values for GNU at the highest $\mathrm{N}$ intakes, taken from Fig. 5, agree quite closely with the corresponding values calculated from equation (7). The apparent maxima in GNU must be interpreted cautiously since they are artifacts of this method of description, which by definition results in zero values at maintenance, whereas the estimate of the true efficiency of $\mathrm{N}$ utilization (i.e. NPU) at maintenance given previously was 0.61 . Similar comments apply to any index of efficiency, such as protein efficiency ratio (Jacquot \& Peret, I972), which involves measurement only of gains above maintenance.

Results shown in Fig. 5 also suggest that NPU does not vary appreciably with W, in 
agreement with Fig. 2 and Homb (1972). Furthermore although NPU decreases with $\mathrm{N}$ intake or more strictly with dietary CP concentration (Payne, 1972), it seems that this effect may be uniform over a wide range of $\mathrm{W}$.

\section{CONCLUSIONS}

It is clear that the relationships between $\mathrm{NR}, \mathrm{N}$ intake and $\mathrm{W}$ follow well-defined patterns in pigs of the same genotype and endocrine status, but are modified by factors such as energy intake, protein quality and sex. Probably other factors such as breed, food deprivation, compensatory growth, feeding regimen, ambient temperature and stress also influence these relationships. However, it is probable that within these limits the relationships referred to in this paper are the major determinants of protein requirements and of the responses of pigs in the important production criteria to variation in dietary protein status. It would therefore seem important to be able to define these relationships more precisely than is possible at present.

Of prime significance is the need to verify the quantitative relationship between NR and W (Fig. I), to determine the influence of sex (and genotype if warranted) on this relationship and to determine the associated $\mathrm{N}$ intakes of a reference protein. From such basic information, it should be possible, using available estimates of obligatory $\mathrm{N}$ losses and $N_{m}$, to derive NR response curves for different $\mathrm{W}$ to variation in protein intake and quality which would be idealized versions of those shown in Figs. 2 and 3. Such curves would provide the basis for subsequent determination or calculation of protein requirements (as indicated in this paper using the limited information available at present), desired values for $\mathrm{CP}: \mathrm{ME}$, food allowances and production responses.

Information presented here suggests that the classical indices of protein quality, such as BV or NPU, are unlikely to be influenced significantly by variation in either W of the test animals used, from infancy to almost mature size, or $\mathrm{N}$ intake at approximately maintenance. In contrast, measures of the efficiency of dietary protein utilization which are used frequently in farm animal nutrition, for example GNU, and which are based only on gains above maintenance, are influenced considerably by variation in each of these factors. Consequently care should be taken in their interpretation.

The authors thank Dr J. E. Bessell and Dr J. Sherrington (University of Nottingham School of Agriculture) and Professor R. J. Townsley (Massey University) for their advice and statistical analysis of data.

\section{REFERENCES}

Agricultural Research Council (1967). The Nutrient Requirements of Farm Livestock No. 3, Pigs. London: Agricultural Research Council.

Agricultural Research Council (1975). The Nutrient Requirements of Farm Livestock No. I, Poultry. London: Agricultural Research Council.

Allison, J. B. (1964). In Mammalian Protein Metabolism, vol. 2, p. 4I [H. N Munro and J. B. Allison editors]. New York: Academic Press.

Armstrong, D. G. \& Mitchell, H. H. (1955). F. Anim. Sci. 14, 49.

Balch, C. C. (1967). Wld Rev. Anim. Prod. 3, 84 .

Bayley, H. S. \& Summers, J. D. (1968). Can. F. Anim. Sci. 48, I8r. 
Bell, J. M. (1965). Can. F. Anim. Sci. 45, 105.

Bell, J. M. \& Loosli, J. K. (195 r). F. Anim. Sci. ro, 50.

Black, J. L. \& Griffiths, D. A. (1975). Br. F. Nutr. 33, 399.

Braude, R., Mitchell, K. G., Newport, M. J. \& Porter, J. W. G. (1970). Br. F. Nutr. 24, 501.

Braude, R. \& Newport, M. J. (1973). Br. F. Nutr. 29, 447.

Braude, R., Newport, M. J. \& Porter, J. W. G. (1971). Br. F. Nutr. 25, I I 3.

Brody, S. (1945). Bioenergetics and Growth. New York: Hafner Publishing Co. Inc.

Calloway, D. H. \& Margen, S. (1971). F. Nutr. Ior, 205.

Chamberlain, A. G. (1972). In Pig Production, p. 203 [D. J. A. Cole, editor]. London: Butterworths.

Chan, H. \& Waterlow, J. C. (I966). Br. F. Nutr. 20, 775.

Charette, L. A. (196I). Can. F. Anim. Sci. 41, 30.

Cooke, R., Lodge, G. A. \& Lewis, D. (1972). Anim. Prod. 14, 219.

Davies, J. M. \& Lucas, I. A. M. (1972). Anim. Prod. 15, 127.

Duncan, D. L. ( 1 966). In Recent Advances in Animal Nutrition, p. 5 I [J. T. Abrams, editor]. London: J. \& A. Churchill.

Elsley, F. W. H., Anderson, D. M., McDonald, J., Macpherson, R. M. \& Smart, R. (1966). Anim. Prod. 8, 391.

FAO/WHO (1973). Wld Hlth Org. Tech. Rep. Ser. no. 522.

Fuller, M. F. (1965). Br. F. Nutr. 19, 53 I.

Fuller, W. A. (1969). Aust. F. agric. Econ. 13, 35.

Heard, C. R. C. (1964). Proc. Nutr. Soc. 23, 110.

Homb, T. (1972). Festskrift Til Knut Brierem, p. 6r Gjøvik: Mariendals Boktrykkeri, A.S.

Jacquot, R. \& Peret, J. (1972). In Protein and Amino Acid Functions, p. 3 I7 [E. J. Bigwood, editor]. Oxford: Pergamon Press.

Jones, A. S., Hepburn, W. R. \& Boyne, A. W. (196r). F. Sci. Fd Agric. 12, 353.

Kielanowski, J. (1967). Proc. 9th int. Congr. Anim. Prod. p. 2 I 2.

Kielanowski, J. (r972). In Pig Production, p. I83 [D. J. A. Cole, editor]. London: Butterworths.

Kleiber, M. (I961). The Fire of Life. New York: John Wiley and Sons Inc.

Kleiber, M. (1 964). In Energy Metabolism, p. 427 [K. L. Blaxter, editor]. London: Academic Press.

Leroy, A. M. (1965). Wld Rev. Anim. Prod. r, 31 .

Lodge, G. A., Hardy, B. \& Lewis, D. (1972). Anim. Prod. 14, 229.

Lucas, I. A. M. \& Miles, K. L. (1970). Anim. Prod. 12, 403.

McLaughlan, J. M. \& Campbell, J. A. (r 969). In Mammalian Protein Metabolism, vol, 3, p. 39I [H. N. Munro, editor]. New York: Academic Press.

Manners, M. J. \& McCrea, M. R. (I963). Br. F. Nutr. I7, 495.

Miller, D. S. \& Payne, P. R. (1963). F. theor. Biol. 5, I398.

Miller, D. S. \& Payne, P. R. (1964). Proc. Nutr. Soc. 23, i I.

Miller, G. M., Becker, D. E., Jensen, A. H., Harman, B. G. \& Norton, H. W. (I969). J. Anim. Sci. 28, 204.

Morgan, D. J., Cole, D. J. A. \& Lewis, D. (1975). F. agric. Sci., Camb. 84, 7.

Munro, H. N. (1964). In Mammalian Protein Metabolism, vol. I, p. 38I [H. N. Munro and J. B. Allison, editors]. New York: Academic Press.

Munro, H. N. (1969). In Mammalian Protein Metabolism, vol. 3, p. I33 [H. N. Munro, editor]. New York: Academic Press.

National Research Council (1973). Nutrient Requirements of Domestic Animals No. 2, Nutrient Requirements of Swine. Washington, DC: National Research Council.

Nielsen, A. J. (197r). Arsskrift, p. 81. Copenhagen: K. Veterinaer-og Landbohøjskole.

O’Hea, E. K. \& Leveille, G. A. (I969). Fedn Proc. Fedn Am. Socs exp. Biol. 28, 687 Abstr.

Oslage, H. J. \& Fliegel, H. (1964). In Energy Metabolism, p. 297 [K. L. Blaxter, editor]. London: Academic Press.

Payne, P. R. (1972). In Protein and Amino Acid Functions, p. 259 [E. J. Bigwood, editor]. Oxford: Pergamon Press.

Piatkowski, B. \& Jung, H. (1966). Arch. Tierz. 9, 307.

Prescott, J. D. H. \& Lamming, G. E. (1967). Anim. Prod. 9, 535.

Rérat, A. (1972). Nutr. Abstr. Rev. 42, 13.

Rérat, A. \& Henry, Y. (1964). Annls Zootech. 13, 5.

Rippel, R. H., Harman, B. G., Jensen, A. H., Norton, H. W. \& Becker, D. E. (1965). F. Anim. Sci. 24, 209.

Rutledge, E. A., Hanson, L. E. \& Meade, R. J. (rg6r). F. Anim. Sci. 20, 142.

Scrimshaw, N. S., Davy, W., Perera, A. \& Young, V. R. (1976). F. Nutr. I06, $66_{5}$.

Stobo, I. J. F. \& Roy, J. H. B. (1973). Br. Y. Nutr. 30, i I 3 .

Sugahara, M., Baker, D. H., Harman, B. G. \& Jensen, A. H. (1969). F. Anim. Sci. $29,598$.

Thorbek, G. (I 969a). In Energy Metabolism of Farm Animals, p. 28I [K. L. Blaxter, J. Kielanowski and G. Thorbek, editors]. Newcastle upon Tyne: Oriel Press. 
Thorbek, G. (1969b). Nutrition, p. 5. London: US Feed Grains Council.

Verstegen, M. W. A., Close, W. H., Start, I. B. \& Mount, L. E. (1973). Br. F. Nutr. 30, 2 I.

Waterlow, J. C. (1 969). In Mammalian Protein Metabolism, vol. 3, p. 325 [H. N. Munro, editor]. New York: Academic Press.

Whittemore, C. T. \& Fawcett, R. H. (1974). Anim. Prod. 19, 221.

Wood, A. J. \& Groves, T. D. D. (1965). Can .F. Anim. Sci. 45, 8.

Wyllie, D., Speer, V. C., Ewan, R. C. \& Hays, V. W. (1969). F. Anim. Sci. 29, 433.

Young, V. R., Steffee, W. P., Pencharz, P. B., Winterer, J. C. \& Scrimshaw, N. S. (1975). Nature, Lond. 253, 192. 